\title{
Habitat Usage of the Thumbprint Emporer Lethrinus harak (Forsskål, 1775) in an Indo-Pacific Coastal Seascape
}

\author{
Richard K.F. Unsworth ${ }^{*}$,, Pelayo Salinas De León ${ }^{\mathrm{b}}$, Samantha L. Garrard ${ }^{\mathrm{c}}$, David J. Smith ${ }^{\mathrm{d}}$ and \\ James J. Bell ${ }^{\mathrm{b}}$
}

\author{
${ }^{a}$ Northern Fisheries Centre, Department of Primary Industries and Fisheries, P.O. Box 5396, Cairns, QLD, 4870, \\ Australia \\ ${ }^{b}$ Centre for Marine Environmental and Economic Research, School of Biological Sciences, Victoria, University of \\ Wellington, Po Box 600, Wellington, New Zealand \\ ${ }^{c}$ Marine Biology and Ecology Research Centre, Davy Building, Drake Circus, Plymouth, PL4 8AA, UK \\ ${ }^{d}$ Coral Reef Research Unit, Department of Biological Sciences, University of Essex, Wivenhoe Park, Colchester, \\ CO4 $3 S Q, U K$
}

\begin{abstract}
Age dependent habitat usage of the abundant Indo-Pacific Thumbprint Emporer Lethrinus harak was assessed using field visual observations throughout the mangrove, seagrass, coral reef continuum. Juveniles were most abundant within seagrass habitats, whilst large adults only utilised the reef environment, indicating a movement towards the reef with increasing age. No evidence was found to suggest $L$. harak spends a specific section of its life-cycle within mangrove however it remains an important habitat, presumably for tidally dependent feeding.
\end{abstract}

Keywords: Connectivity, juvenile fishes, mangrove, seagrass.

\section{INTRODUCTION}

Tropical coastal seascapes commonly comprise seagrass beds, mangroves and coral reefs, which are highly connected by the exchange of water, facilitating the movement of many fish and invertebrates $[1,2]$. The conservation management of tropical ecosystems is most successful when based on an understanding of the interconnectivity between different habitat components [3]. Unfortunately, the mechanisms under-pinning connectivity processes remain poorly understood throughout most coastal regions, particularly the IndoPacific $[1,4]$. Changes in habitat use throughout the life cycle of many abundant and economically important IndoPacific fish, such as the Thumbprint Emperor Lethrinus harak remains poorly documented.

Although mangroves are generally considered important habitat for juvenile reef fish $[2,5]$ this is not always the case in the Indo-Pacific, where mangroves may only play a very limited nursery role for coral reef fish [6, 7]. Caribbean research has recently documented that the value of seagrass and mangrove as nursery habitats should not be generalised a priori, since habitat configuration may interact with the degree of connectivity between seagrasses, mangroves and coral reefs [5].

The food requirements of some fish species change according to their life stage [8], as do their requirements for shelter from predation [9]. As food resources vary between habitats (i.e. seagrass, reef and mangrove), juvenile fish at

\footnotetext{
*Address correspondence to this author at the Northern Fisheries Centre, Department of Primary Industries and Fisheries, P.O. Box 5396, Cairns, QLD, 4870, Australia; E-mail: richardunsworth@ hotmail.com
}

different life stages may undertake staged inter-habitat migrations driven by resource availability [8]; such dietary induced migrations have been termed 'ontogenetic dietary shifts'. The requirement for different habitats at different stages of a species growth may also reflect its need for shelter.

Within the Indo-Pacific region, ontogenetic migrations between seagrass and coral reefs have been reported for numerous fish species [10-12], but the role of mangroves in contributing to these habitat movements with respect to fish age has received limited attention. Studies have only been conducted at the assemblage level, with no species-specific studies. We hypothesise, that as tidally available habitats, where fish can not permanently reside due to reduced water level [1], mangroves in an Indo-Pacific setting do not harbour a specific age range of fish. This would be in contrast to those in the Caribbean that often remain flooded at all times of the tide and contain specific age groups of many fish species [8].

\section{METHODS}

We examined the size frequency distribution of the abundant seagrass, reef and mangrove fish, Lethrinus harak $[7,11,13]$ in five habitat types (reef crest, seagrass/bombies, seagrass, seagrass/mangroves edge, inner mangrove) across three sites, Darawa, Sombano, Langeria (for site descriptions, including environmental and habitat characteristics, see Unsworth et al. 2008 [14]) within the Wakatobi Marine National Park, SE Sulawesi, Indonesia (Fig. 1). Lethrinus harak is a shallow water fish commonly observed to a maximum water depth of 20m [15]. 


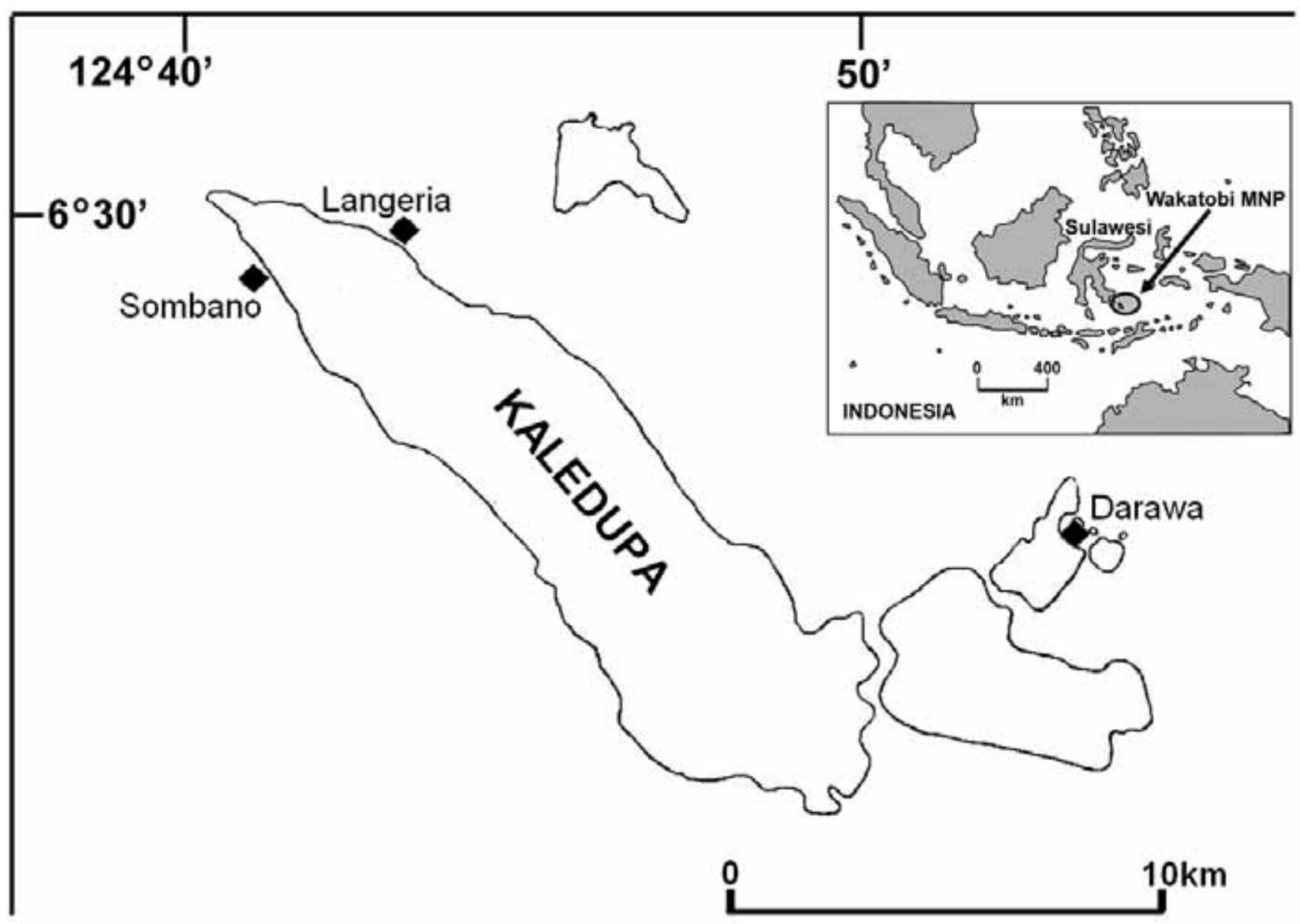

Fig. (1). Location of the three sampling locations within the Wakatobi Marine National Park, Indonesia.

Habitats surveyed were on a classical fringing reef structure containing a shallow water seagrass lagoon and an upper-shore inter-tidal mangrove [16]. The reef flat habitat was defined as $20 \mathrm{~m}$ from the reef crest; the seagrass/bombies habitat was the transition zone of sparse coral colonies intermixed with seagrass at the shoreward edge of the reef flat; the seagrass habitat was defined as approximately $50 \mathrm{~m}$ into the seagrass parallel to the mangroves; the edge of mangrove habitat was defined as $3 \mathrm{~m}$ from the edge and parallel to the mangroves; and the mangrove habitat was $10 \mathrm{~m}$ into the mangrove parallel to the shore (Fig. 2).

Six 50m x 5m visual belt transects at each site and within each habitat type were used to sample the size and abundance of Lethrinus harak (after English et al. 1997 [17]).
Surveys were carried out by snorkelling at high tide during the daytime. Due to the density of mangrove foliage, $50 \times 2$ $\mathrm{m}$ transects were conducted within inner mangrove habitats and data multiplied by 2.5 to allow comparisons with other habitats. Within mangroves it was not always possible to complete the whole $50 \mathrm{~m}$ transect due to the high density of the roots, therefore transects were often broken and restarted at the next available location. Prior to the study, training exercises were conducted in order to accurately assess fish size underwater (see English et al. 1997 for details [17]). All surveys were conducted between June and September 2006. Data was analysed using 'Analysis of variance' (ANOVA) within the software MiniTab v13.

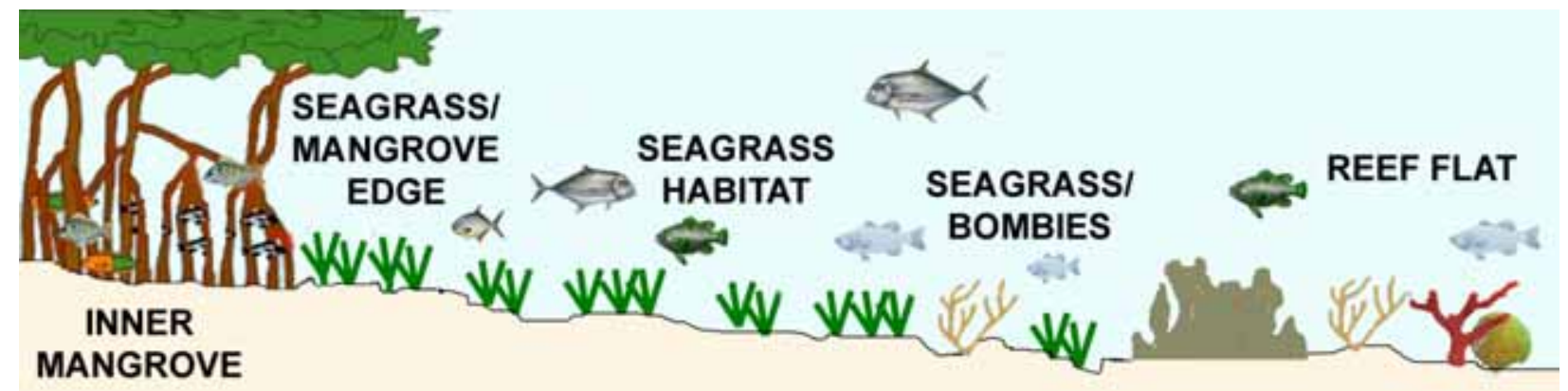

Fig. (2). Schematic representation of the five habitats sampled in the present study. 
Although not a commonly used methodology, mangrove visual census have previously been utilised in Rhizophora mangrove of both the Indo-Pacific and the Caribbean [12,14,18-20]. Difficulties associated with the use of UVC within mangroves, such as observer bias and fish behaviour, are extensively discussed by Nagelkerken et al. (2002) [18]. As with any visual observation method in any vegetated environment, it is likely that small and cryptic species would be underestimated [21].

\section{RESULTS AND DISCUSSION}

Lethrinus harak was present in all habitat types, but significantly differed in abundance $\left(\mathrm{F}_{3,71}=2.3, \mathrm{P}<0.05\right)$. The greatest abundance was recorded in seagrass habitats, decreasing to the seagrass/mangrove edge and inner mangrove (Fig. 3). Abundance in the seagrass/bombie and reef flat habitats was approximately 50\% less than in the other habitats. The mean total length also differed between habitats, with length increasing towards the reef (Fig. 3). This increase in length reflects the proportional reduction in the juvenile to adult ratio from mangrove to reef (Fig. 4).

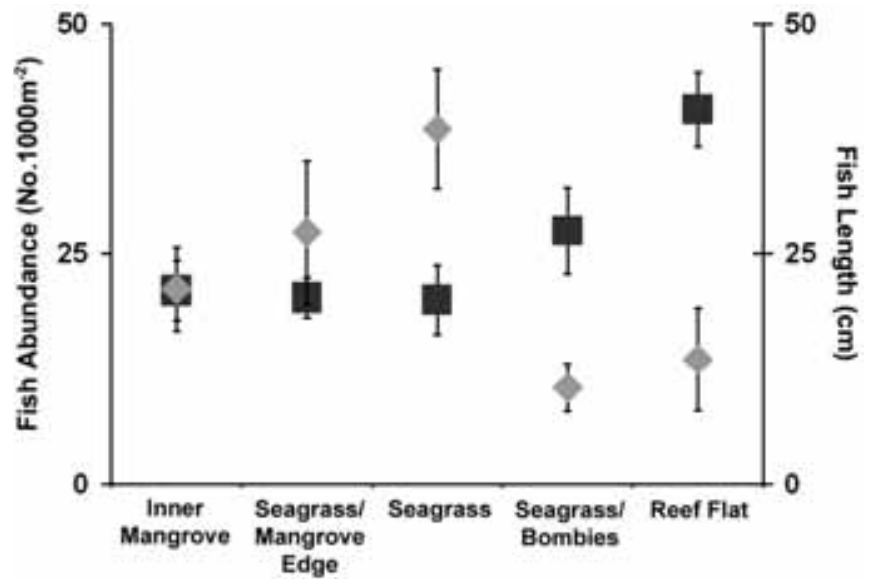

Fig. (3) Mean ( \pm SE) abundance (grey diamonds) and total length (black squares) $(\mathrm{cm})$ of Lethrinus harak in five habitat types averaged across three sites (Darawa, Sombano and Langeria) within the Wakatobi Marine National Park, Indonesia.

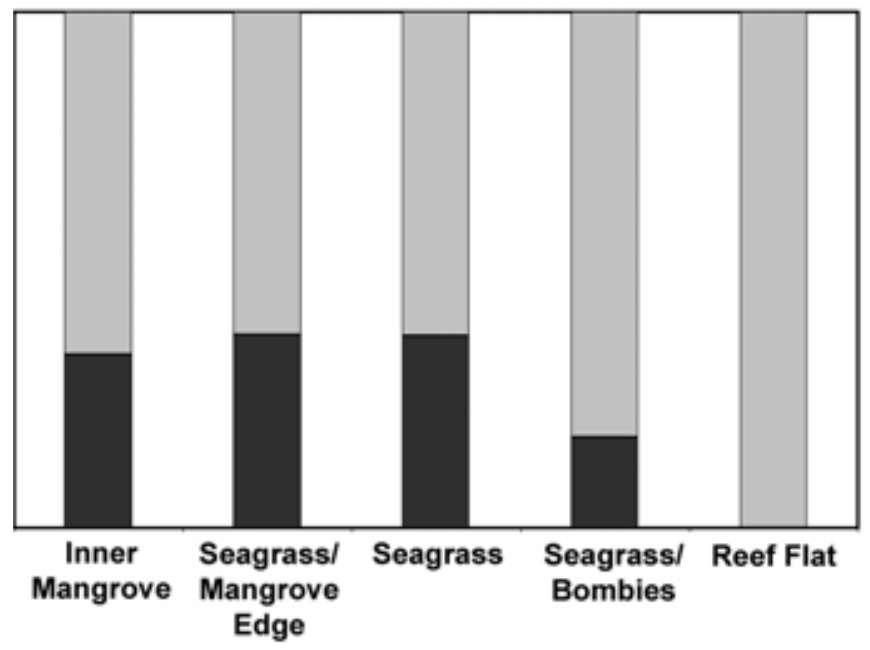

Fig. (4). Mean proportional abundance of juveniles (black bars) and adults (grey bars) of Lethrinus harak in five habitat types averaged across three sites (Darawa, Sombano and Langeria) within the Wakatobi Marine National Park, Indonesia.
The abundance of juvenile $L$. harak (size at maturity defined as $\leq 20 \mathrm{~cm}[22]$ ) differed significantly with habitat $\left(\mathrm{F}_{3,66}=2.79, \mathrm{p}<0.05\right)$ and was unaffected by site. Mangrove, edge of mangrove and seagrass habitats had no difference in juvenile abundance, but tukeys pairwise comparisons determined they contained significantly more juveniles than either seagrass/bombie $(\mathrm{P}<0.05)$ or reef habitats $(\mathrm{P}<0.001)$.

Fish less than $5 \mathrm{~cm}$ were only recorded in seagrass and mangrove habitats, whilst seagrass habitats had at least three fold more fish in the range if $6-10 \mathrm{~cm}$ than any other habitat. This indicates a specificity of this age/size group for seagrass. The overall size frequency distribution between the mangrove and the seagrass/mangrove edge differed very little with the greatest abundance category being $30-40 \mathrm{~cm}$ (Fig. 5). However the seagrass habitat had consistently higher abundance of most size categories. The seagrass/bombie habitat had a broad range of sizes, but an overall low abundance of fish (Figs. 4 and 5). The seagrass/bombie habitat, along with the reef flat, were the only habitats to contain individuals greater than $40 \mathrm{~cm}$. The reef flat habitat only contained mature adult fish greater than 30 $\mathrm{cm}$.

Our results find that Lethrinus harak utilises seagrass and mangrove habitats as nursery grounds and as a larger adult they begin to utilise reef habitats. Although mangrove and mangrove edge habitats are clearly an important habitat for L. harak, we found that they do not harbour a specific size range of fish (different to seagrass habitats), this is probably due to their inter-tidal distribution creating only a temporary, tidally available habitat. An important finding of this research is that seagrass habitats contained at least three times more individuals in the $6-10 \mathrm{~cm}$ range than any other habitat, indicating that individuals of this size have a habitat preference for seagrass. At this size/age range seagrass habitat may preferentially benefit $L$. harak in terms of dietary requirements as well as shelter from predators. Patterns of increasing length of Haemulidae and Lutjanidae were found within different coastal habitats of the Caribbean to be a result of dependency on changing food sources with different ages of maturity [8]. Such patterns within the present study may also reflect the different food resources within different habitats, but may also reflect responses of smaller individuals to greater shelter requirements from predation $[11,23]$.

Due to the inter-tidal nature of these mangroves, the tidal movement of $L$. harak is of critical importance in understanding their habitat usage. As the mangrove is dry at low tide the very presence of this species in mangrove suggests a movement with respect to increasing tidal height $(2 \mathrm{~m}$ local tidal range). Even small individuals of $<6 \mathrm{~cm}$ (recorded within the mangrove) have made this movement, probably from seagrass, the even spread of this size/age group across seagrass and mangrove habitat suggests no preference any habitat and suggests that many small individuals may move passively with the tide between these habitats, possibly search for food in amoungst the shelter of either seagrass shoots or mangrove prop roots.

Our research therefore supports previous findings that seagrass is an important nursery habitat for $L$. harak [11, 12, 24]. But in addition to previous studies we found that the nursery function of seagrass habitats in harbouring juvenile L. harak is much greater than that of mangrove. We also found 


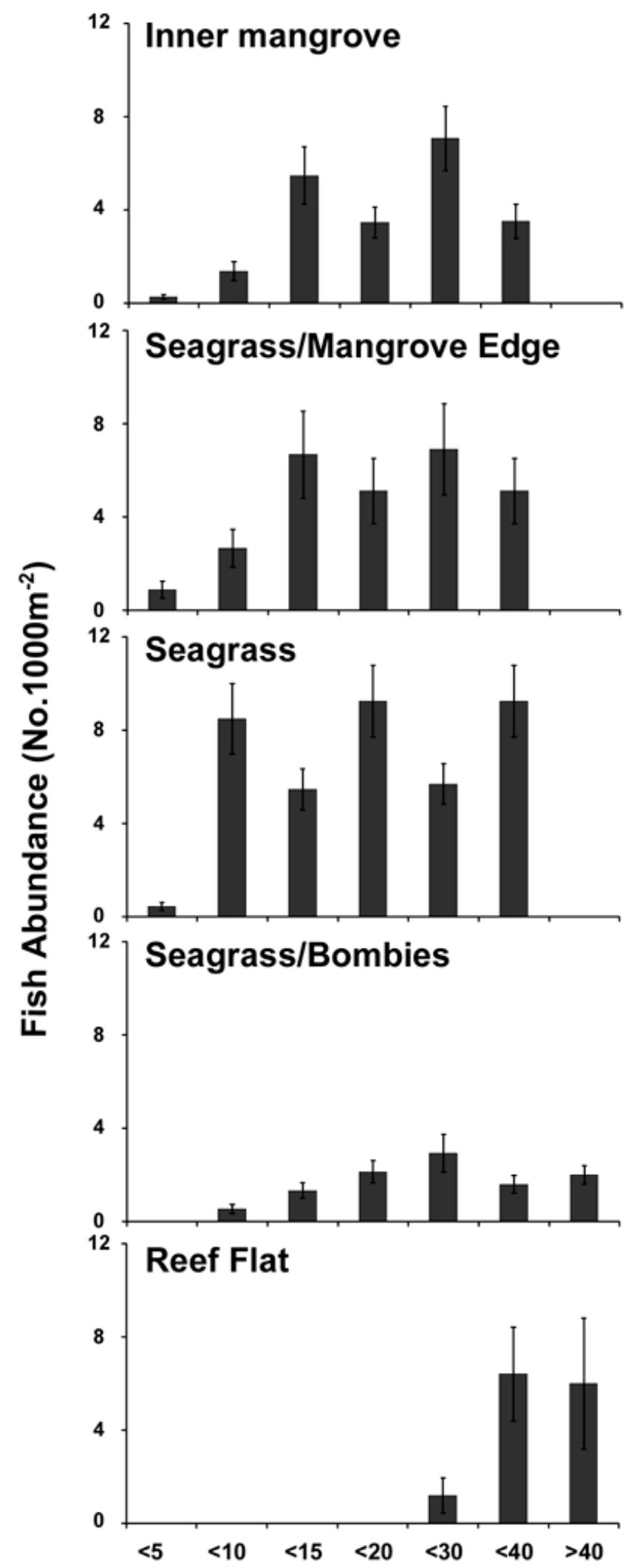

Fig. (5). Mean number $( \pm \mathrm{SE})$ of individuals of Lethrinus harak in each size-class $(\mathrm{cm})$ in five habitat types averaged across three sites (Darawa, Sombano and Langeria) within the Wakatobi Marine National Park, Indonesia.

that seagrass/bombie habitats have only a limited nursery role for $L$. harak. Reef flat habitats contained no juveniles.
Adult individuals utilise all habitats, however, only the largest individuals were found on the reef, which is probably because the largest individuals can capture fast moving prey available on the reef and that they can out-swim larger predators only encountered on the reef.

Coastal invertebrate infaunal assemblages of East Africa and Japan have been found to vary within the inter-tidal to sub-tidal sediments, with particular species and genera harbouring particular depth niches of the seagrass to reef continuum $[25,26]$. Assuming the same patterns exist in Indonesia, this indicates that different resource niches maybe available for different life stages of $L$. harak to utilise. The present study suggests that ontogenetic dietary migrations may cause $L$. harak to utilise seagrass and reef habitats at different life stages, although this was inconclusive for mangroves. Our data supports field observations in Tanzania [10] and analysis of fish stomach contents in Japan [12] that indicated the presence of migrations between seagrass and reef habitats.

Finally we conclude that both seagrass and mangrove are important nursery habitats for an abundant commercial fish species. A greater degree of understanding of the life cycle, movements and feeding behaviour of fish such as L. harak, that utilise an array of different habitats and are economically important to local fisheries [27] would assist with the development of sustainable fisheries management for these threatened habitats.

\section{ACKNOWLEDGEMENTS}

The authors thank the staff at the Hoga Marine Research Centre for logistical support and Operation Wallacea who provided financial support for travel and fieldwork. RKFU acknowledges Operation Wallacea for providing a doctoral studentship and thank LaAmat for field assistance.

\section{REFERENCES}

[1] Sheaves M. Nature and consequences of biological connectivity in mangrove systems. Mar Ecol Prog Ser 2005; 302: 293-305.

[2] Mumby PJ, Edwards AJ, Arias-González JE, et al. Mangroves enhance the biomass of Coral Reef Communities in the Caribbean. Nature 2003; 427: 533-6.

[3] Agardy T. Global marine conservation policy versus site level implementation: the mismatch of scale and its implications. Mar Ecol Prog Ser 2005; 300: 242-8.

[4] Parrish JD. Fish communities of interacting shallow-water habitats in tropical oceanic regions. Mar Ecol Prog Ser 1989; 58: 143-60.

[5] Dorenbosch M, Verberk W, Nagelkerken I, van der Veldel G. Influence of habitat configuration on connectivity between fish assemblages of Caribbean seagrass beds, mangroves and coral reefs. Mar Ecol Prog Ser 2007; 334: 103-116.

[6] Laroche J, Baran E, Rasoanandrasana NB. Temporal patterns in a fish assemblage of a semiarid mangrove zone in Madagascar. J Fish Biol 1997; 51: 3-20.

[7] Dorenbosch M, Grol MGG, Nagelkerken I, van der Velde G. Different surrounding landscapes may result in different fish assemblages in east african seagrass beds. Hydrobiologia 2006; 563: 4560 .

[8] de la Moriniere EC, Pollux BJA, Nagelkerken I, Hemminga MA, Huiskes AHL, van der Velde G. Ontogenetic dietary changes of coral reef fishes in the mangrove-seagrass-reef continuum: stable isotopes and gut-content analysis. Mar Ecol Prog Ser 2003; 246: 279-89.

[9] Nakamura Y, Sano M. Is there really lower predation risk for juvenile fishes in a seagrass bed compared with an adjacent coral area? Bull Mar Sci 2004; 74: 477-82. 
[10] Nakamura Y, Horinouchi M, Nakai T, Sano M. Food habits of fishes in a seagrass bed on a fringing coral reef at Iriomote Island, southern Japan. Ichthy Res 2003; 50: 15-22.

[11] Nakamura Y, Sano M. Overlaps in habitat use of fishes between a seagrass bed and adjacent coral and sand areas at Amitori Bay, Iriomote Island, Japan: Importance of the seagrass bed as juvenile habitat. Fish Sci 2004; 70: 788-803.

[12] Dorenbosch M, Grol MGG, Christianen MJA, Nagelkerken I, van der Velde G. Indo-Pacific seagrass beds and mangroves contribute to fish density coral and diversity on adjacent reefs. Mar Ecol Prog Ser 2005; 302: 63-76.

[13] Unsworth RKF, Bell JJ, Smith DJ. Tidal fish connectivity of reef and seagrass habitats in the Indo-Pacific. J Mar Biol Ass UK 2007; 87: 1287-1296.

[14] Unsworth RKF, De Leon SP, Garrard S, Smith DJ, Bell JJ. High connectivity of Indo-Pacific seagrass fish assemblages with mangrove and coral reef habitats. Mar Ecol Prog Ser 2008; 353: 21324.

[15] Lieske E, Myers R. Collins Pocket Guide. Coral reef fishes. IndoPacific \& Caribbean including the Red Sea: Haper Collins Publishers 1994; Vol. 9. p. 400.

[16] Nybakken JW. Marine biology: An ecological approach. $4^{\text {th }}$ ed, Addison Wesley Educational Publishers Inc. 1997.

[17] English S, Wilkinson C, Baker V. Survey manual for tropical marine resources. Australian Institute of Marine Science: Townsville 1997.

[18] Nagelkerken I, Roberts CM, van der Velde G, et al. How important are mangroves and seagrass beds for coral-reef fish? The nursery hypothesis tested on an island scale. Mar Ecol Prog Ser 2002; 244: 299-305.

[19] Dorenbosch M, Verberk W, Nagelkerken I, van der Veldel G. Influence of habitat configuration on connectivity between fish as- semblages of Caribbean seagrass beds, mangroves and coral reefs. Mar Ecol Prog Ser 2007; 334: 103-16.

[20] Aguilar-Perera A, Appeldoorn RS. Variation in juvenile fish density along the mangrove- seagrass- coral reef continuum in SW Puerto Rico. Mar Ecol Prog Ser 2007; 348: 139-48.

[21] Edgar GJ, Barrett NS, Morton AJ. Biases associated with the use of underwater visual census techniques to quantify the density and size-structure of fish populations. J Exp Mar Biol Ecol 2004; 308: 269-90.

[22] Ebisawa A. Reproductive and sexual characteristics in five Lethrinus species in waters off the Ryukyu Islands. Ichthyol Res 2006; 53: 269-80.

[23] Verweij MC, Nagelkerken I, de Graaff D, Peeters M, Bakker EJ, van der Velde G. Structure, food and shade attract juvenile coral reef fish to mangrove and seagrass habitats: a field experiment. Mar Ecol Prog Ser 2006; 306: 257-68.

[24] Kochzius M. In: Séret B, Sire J, Eds. Interrelation of ichthyofauna from a seagrass meadow and coral reef in the Philippines. Proc 5th Inter Indo-Pac Fish Conf, Nouméa, 1997. Paris: Soc. Fr. Ichthyol 1999.

[25] De Troch M, Gurdebeke S, Fiers F, Vincx M. Zonation and structuring factors of meiofauna communities in a tropical seagrass bed (Gazi Bay, Kenya). J Sea Res 2001; 45: 45-61.

[26] Nakamura Y, Sano M. Comparison of invertebrate abundance in a seagrass bed and adjacent coral and sand areas at Amitori Bay, Iriomote Island, Japan. Fish Sci 2005; 71: 543-50.

[27] Cullen LC. Marine resource dependence, resource use patterns and identification of economic performance criteria within a small island community: Kaledupa, Indonesia. PhD Thesis. Department of Biological Science, University of Essex: Colchester 2007.

(C) Unsworth et al.; Licensee Bentham Open.

This is an open access article licensed under the terms of the Creative Commons Attribution Non-Commercial License (http://creativecommons.org/licenses/by$\mathrm{nc} / 3.0 /$ ) which permits unrestricted, non-commercial use, distribution and reproduction in any medium, provided the work is properly cited. 